\title{
The Use of Brainstorming Strategy to Improve Students' Speaking Ability
}

\author{
Hapri Octarina \\ IAIN Bengkulu \\ hapri@gmail.com \\ Syamsul Rizal \\ IAIN Bengkulu \\ syamsulrizal@gmail.com \\ Fera Zasrianita \\ IAIN Bengkulu \\ ferazasrianita@gmail.com
}

\begin{abstract}
The purpose of this study to investigate whether brainstorming strategy can improve the students' speaking ability. The subject of research was XI IPA 2 in Academic year 2020/2021. The design of this research is classroom action research (CAR). The researcher evaluates the students' speaking in five forms those are, Pronunciation, grammar, vocabulary, fluency and comprehension. Before doing cycle 1 the researcher gave speaking test of pre-cycle, based on the result the test in pre-cycle; the researcher gave treatments of action 1 and action 2 they are planning, implementing, observing and reflecting to see improvement of students' speaking ability after the treatments were given. The brainstorming strategy can improve the students' speaking ability in two cycle. Then the researcher find out there is a significance difference between the mean score of students' speaking ability in cycle $1(62,24)$ and the mean score of students' speaking ability in cycle 2 (75,68). There is impact of cycle 2 and the result can achieve the criteria of success. By comparing the means, the researcher concluded that improvement students' speaking ability through brainstorming strategy is an effective to develop students' speaking skill. Therefore, English teacher are encourage to teach speaking through brainstorming strategy.
\end{abstract}

Keywords: Strategy, Brainstorming, Speaking Ability

\section{A. Introduction}

Speaking is not easy, so learners need extra effort to master the skill of course because we have to really learn. Therefore, English teachers are demanded to be more creative in presenting their lessons, especially the speaking subject since it is considered as the difficult skill to be mastered, learning especially speaking because they are considered to be difficult skills to master, learning to speak is clearly more difficult than learning to understand spoken language. The students are expected to be able to speak English in the classroom along with their mother tongue. They also expected to be able to ask a question 
using English. But the fact some students be passive in the classroom. Where the teachers have tried so many methods and tools to teach speaking skills but they were still low in speaking because the students afraid to make mistakes in grammar and pronunciation.

The way that allows people to communicate is in Brainstorming. According to Isaksen brainstorming is a brief summary or issue of ideas as Osborn who introduces, presenting this famous group approach to the next generation given (Isaksen, 1998). A creativity technique with various efforts made to find conclusions and results for a particular problem by compiling a list of ideas that are spontaneously provided by its members. People can think more freely and they spontaneously suggest as many new ideas as each person has different ideas. All ideas are recorded and accepted without criticism and after the brainstorming session the ideas are evaluated which ones are really needed. Some students are more better successful than others. To find out why, learn the characteristics of students because they have different heads and also their curiosity and interests.

Brainstorming Strategy is one of the strategies used to provoke someone's creativity by releasing their new ideas and solving problems in the fields of education, commercial, industrial and politics. The Brainstorming Strategy was introduced by Alex Osborn, he was a manager at an American advertising company in 1938 which was the result of his inconvenience in meeting with traditional businesses. Brainstorming means the use of the brain to bring out their ideas to solve problems and brainstorming sessions aimed at getting creative solutions to problems.

Brainstorming is a popular method of group interaction in both the educational and business environment because a person's argument is very useful in educational and business development. Although there are matters regarding productivity, brainstorming is still the most widely used method for developing creative solutions. This is a strategy in research and improvement or variation is still continuing and developing. Many of these methods are claimed to be more efficient than original brainstorming.

From the result of pre-observed, there is the level of student awareness in learning English especially speaking is very low, they complain of being bored and do not enjoy when in class, as we know speaking is one of the skills that we must understand. The first problem that also arises is their lack of vocabulary and also lack understanding of grammar, the students also afraid to speak in the classroom, they are sometimes difficult to understand and understand what is speaking because sometimes they are also not given the opportunity 
to speak. But there are also some of them who feel happy and enjoy it because they can hone their ability to speak English no matter the pronunciation and grammar.

Relevant researcher needed to observe several previous kind of researcher conducted by other researcher who are relevant to our research. In addition, we must analyze what points are the focus, inform the design, findings, and conclusion from previous studies, that for: First, Mahtawarni's research focuses on the "Improving students" speaking skill by using Problem based learning (PBL) model a Study at Second Grade Junior High School of SMP N 1 Timang Gaja" the researcher found the result of the questionnaire indicates that the majority of students are happy in learning speaking by using PBL model and most of them believe that the PBL model could help them to express their ideas in speaking and also motivate them in highly learning English. Second, Al-khatib's research focuses on the "The Effect of Using Brainstorming Strategy in Developing Creative Problem Solving Skills among Female Students in Princess Alia University College" the researcher found the effectiveness of using brainstorming strategy In developing creative thinking skills. Third, Budiarti's Research focused on "the use of brainstorming game to improve students' Speaking ability at eight grade students of SMP Negeri Sumber wringin Sukowono Jember In 2015/2016 academic year" the researcher found there is impact of Cycle 2 and the result can achieve the criteria of success. Brainstorming game held by group of students, and the students choose one picture of the animals

Based on the explanation above, the researcher interested to Improve students' ability in speaking with entitled "The Use of Brainstorming to Improve the Students Speaking Ability at the $11^{\text {th }}$ Grade Students' of SMAN 1 Bengkulu Tengah Academic Year 2020/2021"

\section{B. Research Methodology}

This research used or applied the Classroom Action Research (CAR) method. The research conducted is classroom action research. It aims at to find and implement some actions to improve the speaking ability. Which focus on teaching and learning in the classroom. In addition, classroom action research is one of the strategies for solving problems that use concrete actions and analyzing every influence of the situation.

Action in class is a method for finding out what is the best way in class. So, we can improve students' abilities in the learning process. The purpose of this class action research is to improve the teaching of teachers in their own class or school. Although there is no requirement that the findings can be generalized to other situations, the results can add to the 
knowledge base. The subject of the research is class XI MIPA 2 student SMA N 1 Bengkulu Tengah in academy year 2020/2021. This participant of the class consists of 31 students. This classroom action research was conducted collaboratively. The English teacher as the collaborator and the research prepared all the procedures in the research. Hopefully, the result of this research was able to solve problems in speaking ability. The instrument of collecting data is used by the researcher collaborate with English teacher to get the data observation by using: Speaking Test, Observation, Interview, Field note, Study Documentation.

Technique of collecting data in this research using qualitative data (experiencebased) and quantitative data (number-based). The qualitative data consist of observation within the physical activity in the classroom. On the other side, the quantitative data cycle 1 and cycle 2. This research collaborate with English teacher used a classroom action research the method is to know how the teacher can organize her teaching and learning condition from there own experience. She can try an idea as reparation in there teaching and learning process and look the real effect of those efforts.

There are four components in one cycle for doing classroom action research it consists of Planning, Implementing, observing and reflecting. This classroom research is arranged into two cycle they are cycle 1 and cycle 2 . The researcher will collaborate with the English teacher who teaches in $11^{\text {th }}$ class. The criteria of success is used to find out whether the goal of the action is achieved. The score target of vocabulary mastery is 75 based on the minimum score requirement of SMAN 1 Bengkulu Tengah. In this research, the researcher collaborate with English teacher also conducted which has obtained. Which are in form scores of numbers, by evaluating and comparing the result from each cycle in order to know whether the Brainstorming strategy can improve the students speaking ability. Additionally, to support the data analysis, in order to find out the students percentage (Sudijono, 2009), the researcher use formula bellow:

$$
\mathrm{P}=\frac{\mathrm{F} \times 100 \%}{\mathrm{~N}}
$$

Where :

$\mathrm{P}$ : Precentage

$\mathrm{F}$ : Frequency

$\mathrm{N}$ : Total number of students 
When the data has collected it was analyzed to get mean score of the aspect of Speaking.

The data of this research and English teacher were the scores taken from cycle one and cycle two. They were scored to get the data of each aspect if the students' speaking namely pronunciation, grammar, vocabulary, fluency, and comprehension used and relevance the Speaking and compared the means score of aspect cycle. This was done to see in order to see whether there was effect of the action to the students' speaking ability.

The mean score of the class can be searched by using this following formula:

$$
M=\frac{\sum_{\chi}}{\sum_{\gamma}}
$$

Where:

$\mathrm{M}=$ Mean score

$\sum \mathrm{x}=$ Total of Students score

$\sum_{\gamma}=$ Total of Students, (Arif, 2008)

Data are gotten in qualitative data, According to Miles and Huberman the process of analysis in three phases: consisting of data reduction, data display and conclusion.

\section{Results and Discussion}

\section{Results}

The test was given to the students in order to measure the students improvement in speaking ability before and after treatment. The data obtained from cycle 1 and cycle 2 were statistically calculated in order to identify the mean of the scores.

\section{a. Pre-Cycle}

At the beginning of the research collaborate with English teacher as a assess of speaking test, the researcher and English teacher gave pre-test to the students. The aim of the test was get information about students' basic skill in speaking. It was conducted on July 27, 2020 at SMAN 1 Bengkulu Tengah $11^{\text {th }}$ grade students. When the data has collected it was analyzed of the aspect of speaking such as: pronunciation, grammar, vocabulary, fluency and comprehension. It was done in order to decide the treatment which would focus on in the next cycle.

The Result of Pre-Cycle based on assess English teacher can be seen of the table below: 
Table 4.1: The Result of Pre-Cycle based on assess English teacher

\begin{tabular}{|l|l|c|l|}
\hline Score interval & Category & Frequency & \\
\hline $80-100$ & Good & 0 & $\%$ \\
\hline $60-79$ & Moderate & 10 & \\
& & 15 & $4,48 \%$ \\
\hline $40-59$ & Poor & 4 & $2 \%$ \\
\hline $0-39$ & & & $4 \%$ \\
\hline
\end{tabular}

Based on the table above, the students speaking ability is still poor, based on the pre-assesment were: 0 students include "good" category; 10 students include "moderate" category; 15 students include "poor" category; 4 students include "very poor" category. And then it show that students ability in speaking needed improvement. Means of the students score $(56,39)$. The calculation showed that the students average in listening ability was "poor" category. Base on the data above, it is important that the researcher gave the treatments in cycle 1 , and next cycles.

Based on the results of the study, students' speech skills are still poor, based on pre-assessment are: 0 students belong to the category of "good"; 10 students fall into the "moderate" category; 15 students fall into the "poor" category; 4 students fall into the "very poor" category. And then show that students' ability to speak requires improvement. Student grade facility (56.39). Calculations show that the average student in listening ability is in the "poor" category. Based on the data above, it is important that researchers provide care in cycle 1 , and the next cycle.

\section{b. Cycle 1}

Based on the evaluation, this cycle was done as follow up of the pre-cycle. The researcher has found that some of the students could not speaking well. They made mistakes in content (development of subject details), determining, pronunciation, grammar, vocabulary, fluency and comprehension, there are some weaknesses in teaching and learning process such as lack of the teachers' motivation, lack of students' participation because in teaching and learning process. In this session researchers and English teachers as 
collaborators implemented brainstorming strategies to help students improve their speaking skills. Speaking Test in Cycle 1 was conducted on August 3, 2020.

Table 4.2: The Students Result of Cycle I on assess by English teacher

\begin{tabular}{|c|c|c|c|}
\hline Score interval & Category & Frequency & \\
\hline $80-100$ & Good & 1 & \\
\hline & & & ,44\% \\
\hline $60-$ & Mod & 17 & \\
\hline 79 & erate & & $8,62 \%$ \\
\hline $40-$ & Poor & 12 & \\
\hline 59 & & & $41,37 \%$ \\
\hline & Very & 0 & \\
\hline 39 & Poor & & $\%$ \\
\hline
\end{tabular}

Based on the table above, the students speaking ability is still poor, based on the

Cycle I were: 1 students include "good" category; 17 students include "moderate" category; 12 students include "poor" category; 0 students include "very poor" category. And then it show that students ability in speaking needed improvement. Means of the students score $(62,24)$ (see appendix 2). The calculation showed that the students average in speaking ability was "poor" category. Based on the data above, it is important that the researcher gave the treatments in cycle 2 , and next cycles.

\section{c. Cycle 2}

In this cycle, the researcher was focus on the treatment on the content (development of subject details), and Pronunciation, Grammar, Vocabulary, Fluency and Comprehension. The speaking test in cycle II was conducted on August 24, 2020. The researcher though the students how to control the content of their speaking and how to apply pronunciation, grammar, vocab, fluency and comprehension in speaking. The researcher gave an example and asked the students to do exercises. And the researcher will give the students a motivations and participation in teaching and learning process with asked to them about their experiences or person them like that the relationship with the descriptive material.

Table 4.3: The Students Result of Cycle II on assess by English teacher

\begin{tabular}{|r|lr|l|r|}
\hline $\begin{array}{r}\text { Sc } \\
\text { ore interval }\end{array}$ & gory & Cate & Freq & \\
& & uency & & \\
\hline
\end{tabular}




\begin{tabular}{|c|c|c|c|}
\hline 100 & d & 9 & $1,03 \%$ \\
\hline 79 & Mod & 20 & $8,95 \%$ \\
\hline 59 & Poor & 1 & ,44\% \\
\hline 39 & $\begin{array}{ll} & \text { Very } \\
\text { Poor }\end{array}$ & 0 & $\%$ \\
\hline
\end{tabular}

Based on the table above, the students speaking ability is still poor, based on the Cycle I were: 9 students include "good" category; 20 students include "moderate" category; 1 students include "poor" category; 0 students include "very poor" category. And then it show that students ability in speaking was improvement. Means of the students score $(75,68)$ (see appendix 2). The calculation showed that the students average in speaking ability was "moderate" category. Base on the data above, it is stop to give treatments.

d. Data analysis

Based on the data analysis above, the researcher found that the results of this result of this research have answered the research question, that is can brainstorming strategy improve students' speaking ability at $11^{\text {th }}$ grade students of SMAN 1 Bengkulu Tengah.

e. Teaching and learning Process

In this study, The researcher collaborate with English teacher at SMAN 1 Bengkulu Tengah his name is Hariyantoni, M.Pd. the researcher designing the lesson plan and the strategy and then the English teacher applied the strategy to teach the students at class XI MIPA 2. The teaching and learning process is very significant where students initially feel bored and not excited, lack of motivation to learn English. But as a teacher we must know what is happening starting from approaching students and providing motivation in the process of teaching and learning activities.

After giving a little explanation and giving a little motivation for students in the class, there is already an interest in participating in learning activities.

The students are very flexible and excited about the strategies applied. Dare to interact with friends and also don't hesitate to ask if someone doesn't understand. 
In the process of teaching and learning activities, students are expected to be always enthusiastic and not quickly bossed by new strategies or new methods that can be applied in teaching and learning activities.

\section{Discussion}

Based on the previous chapter, by cycle 1, cycle 2 and Observation it was found that there is was gradual improvement on the students' speaking ability. The result of this research was compared to some theorist and ideas explained in chapter 2 . The improvement of students' means score in pre cycle that 56,39 increase to 62,24 in cycle 1 . Moreover cycle 2 was the cycle that improved Students' speaking ability that means score 75,68.

Based on improvement of each cycle, brainstorming strategy improved students' speaking ability. the result of this research was also similar to result some previous studies. Firstly the result of the research by Diah Fifin Budiarto (2016) entitled "The Use of Brainstorming Game to Improve Students' Speaking Ability at Eight Grade Students of SMP Negeri Sumber Wringin Sukowono Jember in 2015/2016." That research method is classroom action research (CAR). The result of the research findings and showed that the Brainstorming game with the use of speaking activities in classroom. The brainstorming game can be applied in teaching speaking. They also had adequate opportunities to practice speaking in order to speak fluently and confidently. Speaking ability In two cycle The percentage is $40 \%$ of students who got score $\geq 60$. in Cycle 1 to $(E=73.33 \%)$ in Cycle 2. it can make the improvement in some aspect of speaking skills such as vocabulary, grammar, pronunciation, fluency and comprehension. This research was similarity to the result of this research was through brainstorming can be improve the students' speaking ability (Diah Fifin, 2016).

Secondly, the result of the research by Yuni Mahtawani (2016) with entitled "Improving Students Speaking Skills by Using Problem Based Learning (PBL) Model (A Study at second grade Junior high school SMPN 1 Timang Gajah. this research used the quantitative research finding and showed that the T-test indicate that was a significant differences between the score of pretest and post-test. It can make a improvement the Speaking students skill improvement. Similarities in this research was improvement students speaking activities in classroom, and the differences is the method to guide the data (Yuni Mahtawarni, 2016).

Thirdly, the research by Bilal Adel Al-Khatib (2012) with entitled "The Effect of Using Brainstorming Strategy in Developing Creative Problem Solving Skills Among 
Female Students in Princess Alia University" this research used the quasi experimental. The result is the finding of study showed that are statistical significant differences at the level of $(\alpha=0.05)$ between the experimental group and the control group in the total score and the sub score creative thinking. It make the effectiveness using the brainstorming strategy to implementing the students in different strategies. The result is similarity to show the brainstorming strategy can applied in classroom. the different in this research is how to collect the data.

Finally, after get through all step the Brainstorming strategy is an effective that the teacher use to teach speaking ability. So, the students' fluency, accuracy covering grammar, vocabulary. pronunciation and comprehension can be improved. From the above explanation and the theory, the brainstorming strategy can be applied in teaching speaking that was able to improve students' speaking ability.

\section{Conclusion}

Based on the previous chapter, it can be concluded that brainstorming strategy can improve students' ability in speaking by giving more practice, more explanation about the way to use brainstorming in speaking teaching and learning proses and ask them to perform their ideas. The students were able to express their ideas more fluently and natural. It makes the students active to be involved in teaching and learning process. By grouping them, they can share their idea. So, the students' fluency, accuracy covering grammar, vocabulary, pronunciation and comprehension can be improved.

The students divided in group pair to make them become more confident to answer the problems or question in white board. It makes students more actively in teaching and learning process. They are can share their ideas to each other. They can speak more and enjoyed during the teaching and learning process. 


\section{References}

Adel, A.K. (2012). The Effect of Using Brainstorming Strategy in Developing Creative Problem Solving Skills among Female Students in Princess Alia University College. American International Journal of Contemporary Research. Vol. 2 No.10; October 2012. www.aijcrnet.com Centre for Promoting Ideas, USA.

Agha, M. (2009). The Effect of Using Brainstorming Strategy in the Development of Some Mathematical Thinking Skills in the Brain Sides of 11th Grade Students (Unpublished master thesis). Faculty of Education, Islamic University, Gaza.

Al-Huwaidi, Z. (2005). Modern methods in teaching science. University Book House, UAE.

Arikunto, S. (2014). "prosedur penelitian, suatu pendelatan praktik", Jakarta: Rineka Cipta.

Brown, D. (2001). Teaching by Principle: An Interactive Approach to Language Pedagogy. New York: Longman.

Brown, D. and George, Y. (2008). Teaching the Spoken Language. Cambridge University Press.

Chandra, S. (2012). Brainstorming. Chirala, Vetapalem, 523 187, India DOI: 10.5923/j.mm.20120204.05.pdf. p. 113 Access on February 01, 2020.

Costello, J.M. (2003) . Action Research. New York: Continuum.

David, H. (1974). Testing English as a Second Language. New York: Mc. Graw. Donough, Mc. \& Shaw, C. J. (2003). Material and Method in ELT, Second Edition (A Teacher Guide). Cornwall: Blackwell Publishing.

Gallupe, R.B.\& Dennis, A.R., Cooper, W.H., J.S. (1992). "Electronic Brainstroming and Group Size", Academy of Management Journal, vol.35, no.2. Teaching. Edinburgh: Addison Wesley Longman.

Gebhard, J.G. (2000). Teaching English as a Foreign or Second Language: A Teacher Self-Development and Methodology Guide. Ann Arbor: The University of Michigan Press.

Haberberg, A. and Rieple, A. (2008). "StrategicManagement", Oxford University Press, New Delhi.

Harmer, J. (1990). The Practice of Language Teaching Third Edition. USA: Longman. Harmer. J. (2000). How to Teach English: An Introduction to the Practice of English Language. USA: Longman.

Hughes, R. (2006). Spoken English TESOL and Applied Linguistic Challenges for Theory and Practice. PALGRAVE MACMILLAN: NEW YORK.

Kelly, K. S. (2008)."Productive Brainstorms Take the Right Mix of Elements", The Wall Street Journal. Access on February 01, 2020.

Martin K. (2016). Professional Learning Board "How can I Facilitate Brainstorming in the Classroom?"

https://k12teacherstaffdevelopment.com/tlb/how-can-i-facilitate-brainstorming-in-the-clas sroom/acsess on 3 march, 2020.

Masri, A. (2019). The Impact of Using Brainstorming in the Development of Creative Thinking and Achievement in the English Language of the 10th Grade Students at King Abdullah II Schools of Excellence in Amman. International Education Studies; Vol. 12, No. 2; 2019 ISSN 1913-9020 E-ISSN 1913-9039. https://doi.org/10.5539/ies.v12n2p82. 
Miles, M. B. \& Huberman, M. H. (2005) Michael Huberman.Qualitative Data Analysis (terjemahan).Jakarta : UI Press.

Nunan, D. 1991. Language Teaching Methodology: A Text Book For Teacher. New York: Prentice Hall International, Ltd.

Pachler, N. and Redondo, A. (2007). A Practical Guide to Teaching Modern Foreign Language in Secondary School. Routledge: New York.

Santanen, E., Briggs R.O. \&, Vreede, G.J. (2004) "Causal Relationships in Creative Problem Solving: Comparing Facilitation Interventions for Ideation", Journal of Management Information Systerms.

Sudijono, A. (2009). pengantarstatistic pendidikan. Raja wali Press.

Sugiyono. (2013) . MetodePenelitianKombinasi (Mixed Methods). Bandung: Alfabeta. Theresa M.K. (2001) Put the test: tools and technique for classroom Assessment. New York. 2001.

Tiro, M. A. (2008). Dasar-Dasar Statistika. Makassar: Andira Publisher.

Ur, P. (1995). A Course in Language Teaching Practice. New York: Cambridge University.

Ur, P. (1996). A Course in Language Teaching Practice and Theory. New York: Cambridge University Press.

Ur, P. (2000). A Course in Language Teaching. Cambridge University.

Ur, P. (2009). Teaching Listening Comprehension. Cambridge University Press.

Yazdanpanahi, T. (1995). "Personality differences and group versus individual brainstorming. Personality and Individual Differences", vol.19 